Avoimesti luettavissa osoitteessa http://journal.fi/ainedidaktiikka

\title{
ainedidaktiikka
}

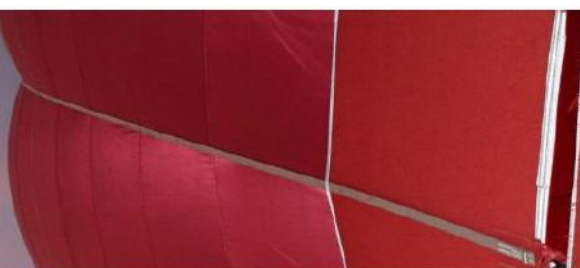

\section{Kuinka käsitellä maailman ongelmia? Traagisuus ja toivo ympäristökasvatuksessa}

\author{
Panu Pihkala
}

Teologinen tiedekunta, Helsingin yliopisto

\begin{abstract}
Artikkeli tarkastelee ympäristökasvatuksen haasteita nykytilanteessa, jossa ympäristökysymysten suhteen esiintyy erilaisia psykologisia torjuntareaktioita. Ympäristökasvatus ymmärretään tässä laajasti: se sisältää myös kestävän kehityksen kasvatuksen ja sen toteuttamisalana ovat eri oppiaineet sekä kasvatustilanteet. Artikkelin metodina on systemaattinen analyysi eri tieteenalojen tutkimustuloksista ja niissä käytettävien käsitteiden merkityksestä. Analyysin perusteella esitetään suosituksia siitä, millä tavoin ympäristökasvatuksessa olisi tuotava esiin sekä traagisuutta että toivoa. Maailman ongelmia on käsiteltävä riittävällä vakavuudella, jotta ihmiset pitävät ympäristökasvatusta uskottavana ja kokemusmaailmaansa vastaavana. Samalla on huolehdittava siitä, että draaman kaari vie kohti voimaantumista, jossa toivo on keskeinen merkityksen antaja. Artikkeli tarkastelee narratiivien, tunteiden, eksistentiaalisten kysymysten ja henkisyyden roolia tällaisessa ympäristökasvatuksessa. Se päätyy suosittelemaan taideperustaisten menetelmien käyttöä.
\end{abstract}

ympäristökasvatus, filosofia, viestintä, psykologia, uskontotiede

Lähetetty: 17.2.2017

Hyväksytty 1.6.2017

Vastuukirjoittaja: panupp@yahoo.com

orcid: 0000-0002-6876-8011 


\section{Johdanto}

Maailman ympäristöongelmat ovat monin tavoin erittäin vakavia ja vaativat reagointia eri tasoilla, mukaan lukien kasvatuksessa ja opetuksessa. Viralliset ohjeistukset suosittelevat ympäristökasvatuksen toteuttamista läpileikkaavasti hyvin erilaisissa oppiaineissa (opetussuunnitelmien osalta ks. Mykrä 2016). Ympäristöongelmien vakavuus on kuitenkin luonut uhkakuvien ilmapiirin, jossa opettajat ja kasvattajat kamppailevat sen kanssa, millä tavoin näitä vakavia ongelmia tulisi käsitellä.

Uhkakuvat ympäristön tuhoutumisesta ja ympäristöliikehdintä liittyvät kiinteästi yhteen, koska nykyisenkaltainen ympäristöliike muotoutui uhkakuvien ilmapiirissä 1960- ja 1970-lukujen vaihteesta lähtien (Radkau 2014). Noista ajoista lähtien on myös keskusteltu kriittisesti siitä, missä määrin uhkakuvia tulisi käyttâä ympäristöön liittyvässä viestinnässä, mukaan lukien ympäristökasvatuksessa (Berryman \& Sauvé 2013, 134; Gough 2013). Monet ympäristötoimijat ovat ymmärrettävästi kokeneet suurta huolta siitä, millaisia tuhoja on tulossa. Tutkimuksissa on pääsääntöisesti kuitenkin havaittu, että uhkakuviin ja tuhoihin liittyvä viestintä ei ole tehokasta, vaan sillä on taipumus lamauttaa ihmisiä (Dickinson, Crain, Yalowitz \& Cherry 2013). Etenkin voimakas maailmanlopun kuvastoa käyttävä viestintä on ongelmallista myös sen vuoksi, että maailmanlopun ja suurten kriisien ennusteet ovat yleensä osoittautuneet epätarkoiksi tai vääriksi (Marshall 2015, 138-144). Uskonnon ja kulttuurin tutkimuksen näkökulmasta on kiinnostavaa, että ympäristökeskusteluun on ammennettu aineksia ikivanhasta uskonnollisesta apokalyptisestä ajattelusta (Buell 1995, luku 9; Eckersley 2008; Skrimshire [toim.] 2010).

Ympäristökasvatuksen, -viestinnän ja -psykologian kirjallisuudessa onkin pääasiassa korostettu positiivisuuden ja optimismin sanoman tärkeyttä (Chang 2014, 107; Clayton, Manning \& Hodge 2014, 41; Fritze, Blashki, Burke \& Wiseman 2008; Stevenson, Dillon, Wals \& Brody 2013, 514). Tilanne on kuitenkin osittain muuttunut. Avainasemassa ovat tutkimustulokset niin sanotusta ympäristöahdistuksesta ja kieltotiloista (denial). Lisätutkimusta tarvitaan, mutta jo tähän asti on käynyt ilmi, että väestöstä yllättävän suuri osa kokee vakavaa ympäristöhuolta (nuorten osalta ks. tuore Nuorisobarometri 2016: Myllyniemi 2017; Salonen \& Konkka 2017). Tämä ei kuitenkaan aina tule julkisuudessa selkeästi esiin, sillä ympäristötuhot ovat niin suuri uhka sekä psyykelle että yhteisöjen tämänhetkiselle elämäntavalle, että yksilöt ja yhteisöt ajautuvat erilaisiin torjuntareaktioihin. Seurauksena on kieltotila, jossa ihmiset samaan aikaan tietävät ja käyttäytyvät aivan kuin eivät tietäisi (vrt. Cohen 2001).

Tuoreessa kansainvälisessä kirjallisuudessa esitetään, että nykytilanteessa sellainen ympäristöviestintä ja -kasvatus, joka piirtyy liian optimistisena ja positiivisena, ei enää ole laajalti uskottavaa, sillä se ei vastaa ihmisten tunteita eikä tietotasoa (Hicks 2014; Kelsey \& Armstrong 2012; Marshall 2014; Stoknes 2015). Vanha näkemys siitä, että ympäristökasvatuksen on oltava osallistavaa ja voimauttavaa, on yhä pätevä, mutta metodeissa on kiinnitettävä laajempaa huomiota maailman tilanteen riittävän realistiseen käsittelyyn ja ihmisten tuntemusten huomioimiseen. Samalla 
on huomioitava tutkimustulokset siitä, kuinka ihmisen monet ominaisuudet soveltuvat heikosti kaukaiselta tuntuvien uhkien kuten ilmastonmuutoksen käsittelyyn (Marshall 2014; Stoknes 2015).

Tässä artikkelissa tarkastelen vaikuttavan ympäristökasvatuksen edellytyksiä nykytilanteessa. Käytän ympäristökasvatus-termiä kattokäsitteenä, joka sisältää tässä laajasti myös kestävän kehityksen kasvatuksen, ilmastokasvatuksen ja muut soveltuvat alat. Tällä tavoin määriteltynä ympäristökasvatuksen toteuttamisalana ovat hyvin monet eri oppiaineet sekä kasvatustilanteet. Käsittelen ympäristökasvatusta kaikkiin ikäryhmiin liittyvänä toimintana, jota voi eri tilanteissa kutsua kasvatuksen lisäksi vaikuttamiseksi (vrt. advocacy) ja viestinnäksi.

Artikkelin metodina on niin sanottu systemaattinen analyysi eri tieteenalojen tutkimustuloksista ja niissä käytettävien käsitteiden merkityksestä. Metodi on kehitetty systemaattisen teologian oppiaineessa, mikä on oma pääasiallinen koulutustaustani. Systemaattinen analyysi on rakennettu erilaisten tekstianalyyttisten menetelmien pohjalta ja se auttaa hahmottamaan eri kirjoittajien näkemysten tarkkaa sisältöä (Jolkkonen 2007).

Tutkimustehtävän laajuuden vuoksi aineisto ei ole selkeästi rajattavissa, vaan se koostuu relevanteimmiksi katsotuista eri alojen tutkimuksista. Analyysin perusteella esitän suosituksia siitä, millä tavoin ympäristökasvatuksessa olisi käsiteltävä maailman ongelmia, traagisuutta ja toivoa. Tällä pyrin tarjoamaan välineitä hyvin moniin erilaisiin kasvatus- ja opetustilanteisiin. Artikkelin keskeisiä teemoja ovat narratiivien, tunteiden, taideperustaisten metodien, eksistentiaalisten kysymysten ja hengellisyyden roolit tällaisessa ympäristökasvatuksessa.

Monitieteellisen ja filosofisen luonteensa vuoksi artikkelin rakenne sisältää johtopäätösten tekemistä eri alaluvuissa. Aloitan tarkastelemalla kansainvälistä keskustelua kieltotiloista ja ympäristöahdistuksesta.

\section{Ympäristöahdistus ja kieltotilat}

Kansainvälisessä keskustelussa on viime vuosina alkanut vakiintua termi eco-anxiety, jolla tarkoitetaan ympäristöasioihin liittyvää ahdistusta. Hoitotyössä olevat ihmiset ovat havainneet, että osa ihmisistä saa jopa psykosomaattisia oireita, kuten vatsakipua, kuullessaan uutisia ympäristötuhoista. Huomattavasti suurempi osa väestöstä kokee henkisiä oireita, kuten masennusta. (Doherty \& Clayton 2011).

Asian tutkimista vaikeuttaa luonnollisesti se, että ihmisten henkiset reaktiot kumpuavat monien toisiinsa nivoutuvien tekijöiden yhteisvaikutuksesta. Esimerkiksi kainuulaista ihmistä voi hyvin ahdistaa sekä Talvivaaran kaivoksen ympäristötuhot että kaivoksen sulkemiseen liittyvät työpaikkojen menetys. Usein on vaikea osoittaa suoraa syy-seuraus-suhdetta ympäristötuhojen ja ahdistuksen välillä, mutta esimerkiksi terapiatyön pohjalta on löydetty myös tällaista yksilöivää evidenssiä (Clayton, Manning \& Hodge 2014; Stoknes 2015).

Ahdistuksen tarkempi määrittely osoittaa, että asiaan liittyy monia erilaisia tunteita, kuten pelkoa, avuttomuutta, epätoivoa, vihaa ja masennusta (Miceli \& Castelfranchi 2010, ss. 264-265). Myös ympäristötietoisten nuorten keskuudessa on havaittu apatiaa (Zeyer \& Kelsey 2013). Tällaiset tunteet etsivät purkautumiskeinoja. Tilanne synnyttää yksilöllisellä 
ja yhteisöllisellä tasolla erilaisia mekanismeja, joiden avulla ihmiset pyrkivät selviytymään.

Psykologit ja psykoanalyytikot hahmottavat skaalan, jossa varsinainen täysi kieltäminen, esimerkiksi ilmastonmuutoksen suhteen, on vain yksi osa reaktioista. Huomattavasti yleisempiä ovat erilaiset välimuodot, joita voi kuvata esimerkiksi vähättelyn (disavowal) ja dissosiaation termeillä. Esimerkiksi eräs aihepiirin johtava tutkija, Sally Weintrobe (2013), näkee vähättelyn huomattavasti vaarallisemmaksi kuin varsinaisen kieltämisen: huomattavan suuri osa väestöstä turvautuu siihen eikä tee tarpeeksi suuria elämäntapamuutoksia.

Dissosiaatio vuorostaan tarkoittaa toimintamallia, jossa yksilö erottaa asiat toisistaan, tässä tapauksessa yksilölliset valintansa ja maailman ympäristötilanteen. Yksilö kokee painetta tehdä jotain, mutta samalla hän ei haluaisi luopua elintasostaan. Ongelmaksi muodostuu usein myös se, että ympäröivä yhteiskunta ei tunnu tarjoavan riittävän suuria mahdollisuuksia vaikuttaa. Seurauksena on, että yksilö tekee joitain ympäristön kannalta kestäviä valintoja ja perustelee niillä sekä itselleen että lähipiirilleen elämäntapansa oikeutusta. Koska yksilö samalla kuitenkin tiedostaa, ainakin syvällä sisimmässään, etteivät nämä tehdyt muutokset ole riittäviä, puolipiilevä ahdistuneisuus säilyy. (Sapiains, Beeton \& Walker 2015)

Tällaiset ympäristöpsykologiasta nousevat havainnot auttavat ymmärtämään tarkemmalla tavalla ympäristökasvatuksen erästä perusongelmaa, kuilua (gap) kyselytutkimuksissa esiin tulleiden arvojen ja toisaalta havaitun ympäristötoiminnan välillä. Ympäristösosiologia tuo tilanteeseen vielä lisävaloa. Yksilöillä on taipumus vastata kyselyihin tavalla, jonka he ajattelevat olevan yhteisön kannalta soveliasta (Marshall 2014). Joukkopaine vaikuttaa ympäristökäyttäytymiseen myös laajemmin ja ilmiöitä on hyvä tarkastella sekä sosiaalipsykologian että sosiologian kautta.

Yhteisöt ovat kykeneviä luomaan kuin itsestään mekanismeja, joilla ne pyrkivät selviämään vaikeista asioista. Eräs tällainen on sosiaalisesti rakennettu hiljaisuus (socially constructed silence, ks. Zerubavel 2006). Sosiologi Kari Marie Norgaard (2011) on tehnyt kenttätutkimusta sen esiintymisestä ilmastonmuutoksen suhteen norjalaisessa kyläyhteisössä. Norgaard havaitsi, että ihmiset kyllä tiesivät ilmastonmuutoksesta, mutta aihe oli liian kipeä käsiteltäväksi julkisesti. Seurauksena oli, että yhteisö kuin huomaamattaan rajoitti yksilöiden toimintaa aiheen suhteen. Jos joku nosti asian esille, häneen kohdistettiin negatiivista painetta.

Tällaiset yhteisölliset mekanismit aiheuttavat tilanteen, jossa ilmastonmuutoksesta ja ympäristöasioista puhuminen on yksilöille usein vakava uhka statuksen ja identiteetin suhteen (Randall 2013; Stoknes 2015). Tällaisessa tilanteessa on valitettavasti ymmärrettävää, että yksilöiden on vaikea toimia valtavirtaa vastaan. Samalla puolipiilevä ahdistus säilyy (ks. myös Norgaard 2011).

Ympäristötuhojen käsittelyn vaikeuteen liittyy myös muita, hyvin syviä ja vaikeita ulottuvuuksia, joita on tässä mahdollista käsitellä vain lyhyesti. Ympäristötuhot herättävät kuolemanpelkoa ja pelkoa jälkipolvien elämänmahdollisuuksien kaventumisesta, mitkä ovat ihmisille hyvin ahdistavia asioita (Foster 2015; Nicholsen 2002; Pihkala 2017). Teollisuus- 
maiden ihmisistä monet tiedostavat, että heidän resurssi-intensiivinen elämäntyylinsä on sidoksissa kehitysmaiden ihmisten kärsimyksiin ja tuleville sukupolville aiheutettuihin ongelmiin (Pihkala 2016). Tällaisten tekijöiden myötä ilmiökenttään liittyvät myös sellaiset vaikeat asiat kuin syyllisyys ja häpeä, joilla on usein lamauttava vaikutus (Jacquet 2015; Randall 2013).

\section{Erilaiset tarinan kertomisen tavat}

Yllä kuvatut eri alojen tutkimukset liittyvät kaikki tiettyyn perusongelmaan: ihmiset ovat ympäristökysymysten suhteen ahdistuneempia ja toisaalta tiedostavampia kuin usein havaitaan. Nämä tutkimukset paljastavat tärkeitä piirteitä siitä tilanteesta, jossa ympäristökasvatusta ja -vaikuttamista toteuttavat henkilöt joutuvat nykyään toimimaan.

Psykoterapeutti Renée Lertzman (2015) suhtautuu yllä kuvatun tilanteen vuoksi kriittisesti sellaisiin ympäristökasvatuksen tutkimuksessa käytettyihin termeihin kuten kuilu (gap) ja este (barrier). Tilanne on niin monimutkainen, että tällaisten termien käyttö voi antaa liian yksioikoisen kuvan siitä, että ratkaisuja voisi löytyä vain poistamalla tietty este tai silloittamalla tietty kuilu (ks. myös Kollmuss \& Agyeman 2002). Hänen oma kenttätutkimusaineistonsa Yhdysvalloista osoittaa, että kyse on ristiriitaisesta tilanteesta, jossa yksilöt ja yhteisöt etsivät selviytymiskeinoja.

Tällaisessa tilanteessa on mietittävä tarkkaan, miten ympäristötoimintaa koskevat viestit kehystetään (framing). Tuore kansainvälinen tutkimus tarkastelee tätä aiempaa laaja-alaisemmin. Kehystäminen on pääteema kahdessa yleistajuisessa ja harvinaisen poikkitieteellisessä teoksessa: George Marshallin Don't even think about it: Why our brains are wired to ignore climate change (2014) ja Per Espen Stoknesin What we think about when we try not to think about global warming (2015).

Ympäristöviestinnässä käytettävistä tarinatyyleistä, genreistä, keskustelevat vielä laajemmin Smith ja Howe (2015), etenkin ilmastonmuutokseen liittyen. He esittävät, että ihmiset tarkastelevat ympäristöön liittyvässä viestinnässä ikivanhoja tarinallisuuden elementtejä, jotka hahmottuvat esimerkiksi seuraavan kaltaisten kysymysten kautta: Ketkä ovat sankareita ja ketkä vuorostaan konnia? Millainen draaman kaari piirtyy ja mikä rooli minulle itselleni siinä annetaan? Sekä he että Marshall (2014) varoittavat vaikuttajia liiallisesta keskittymisestä pieniin ympäristötekoihin, sillä tällainen viestintä ja kasvatus antavat ongelmallisia piiloviestejä. Ihmiset eivät innostu statistin roolista tarinassa, vaan kaipaavat merkittävämmäksi roolihenkilöksi draamassa. Pienten tekojen ylikorostus voi myös antaa viestin siitä, että tilanne ei lopulta olekaan vakava, jos sen ratkaisu on kerran kiinni minusta ja pienistä valinnoistani.

Marshall ja Stoknes, kuten myös Hicks (2014) sekä Kelsey ja Armstrong (2012), suosittelevat viestinnän ja kasvatuksen kehystämistä tavalla, jossa vaikeudet ja positiiviset mahdollisuudet yhdistyvät. Tarkastelen seuraavaksi tätä kysymystä tragedian teeman kautta.

\section{Tragedian merkitys}

Smith ja Howe (2015) pitävät tragediaa vaarallisena tyylilajina, koska he näkevät sen draamamuotona, joka jättää ihmiset heitä suurempien voimien 
Ainedidaktiikka 1(1) (2017)

riepoteltavaksi ja sitä kautta ehkäisee aktiivista toimintaa. Liityn itse Fosterin (2015) näkemykseen siitä, että tragedia on moniulotteisempi tyylilaji. Tragedia käsittelee vaikeita asioita, kuten pahuutta ja yleensä myös kuolemaa, mutta synkistelyn lisäksi tragedialla on outo puhdistava vaikutus. Tragedian yksi historiallinen tehtävä on ollut myötätunnon herättäminen ja toisaalta arvostuksen herättäminen hyviä asioita kohtaan: tragedia auttaa ymmärtämään, että hyvät asiat ovat katoavaisia (Wallace 2007).

Tragedia käsittelee moniulotteisia asioita ja yksi sen perusjuonteista on se, kuinka hyvä ja paha usein kietoutuvat toisiinsa. Foster (2015) liittää tämän suoraan ympäristökysymyksiin tarkastelemalla sitä, kuinka ihmiskunnan eräistä hyvistä ominaisuuksista, kuten innokkuudesta tieteen ja teknologian kehittämiseen, samalla seuraa käytännössä traagisesti myös pahaa.

Traagisissa taideteoksissa kuten draamoissa on erilaisia narratiivisia kaaria. Eräissä klassisissa tragedioissa ei lopussakaan näy kovin paljon valoa: esimerkkinä toimikoon Shakespearen Kuningas Lear. Toisissa tragedioissa on lopussa kuitenkin saavutettu myös jotain arvokasta. Tämä arvokkaiden asioiden saavuttaminen korostuu entisestään kun irrottaudutaan rajattujen tragedioihin tarkastelusta arkielämään eli siihen, miten ihmiset koko elämässään kokevat traagisuuden. Traaginen draama voi päättyä synkästi, mutta sen äärellä oleminen voi silti synnyttää jotain positiivista arjessa.

Andrew Gibbons (2013a, 2013b) on tarkastellut monipuolisesti tragediaa ja kasvatusta. Hän näkee tragedian hyvin merkittäväksi, mutta samalla muistuttaa sen pakenevan liian yksioikoisia tulkintoja. Tragedia heijastaa ihmiselämän ristiriitaisuutta. Itse lisään, että tragedia heijastaa tärkeällä tavalla maailman tilan ristiriitaisuutta myös ympäristökriisin aikana. Maailman tilanteen traagisuuden toteaminen yhdessä voi olla hyvin vapauttavaa myös sen vuoksi, että tämä auttaa käsittelemään yksilön itsensä kokemaa taakkakuormaa. Monet kirjoittajat ovat havainneet, että useilla ihmisillä on taipumus syyllistää itseään liikaakin ympäristöasioiden suhteen (esim. Randall 2013). Tragedian keskellä elämisen myöntäminen merkitsee, että oma vastuu tunnustetaan, mutta samalla ymmärretään, että yksilön ei pidä kantaa koko maailman taakkoja (vrt. Stoknes 2015, s. 88).

Vaikuttaa siltä, että tragedian taju ja traagisten kertomusten äärellä oleminen auttavat maailman ongelmien käsittelyssä. Tragedia mahdollistaa tietyn realismin ja vaikeiden tunteiden yhteisen käsittelyn. Siirryn seuraavaksi sellaisen ympäristökasvatuksen hahmotteluun, jossa otetaan huomioon yllä kuvatut tutkimustulokset ja niiden soveltamismahdollisuudet. Olennaisena teemana on toivo, jota käsitellään tutkimuksen kohteena olevassa monitieteellisessä kirjallisuudessa runsaasti.

\section{Toivon ja optimismin suhde}

Yllä esitetyn perusteella suosittelen, että ympäristökasvatuksessa tulisi hyödyntää metodeja, joissa tragedian tajun avulla käsitellään vaikeita asioita, menetyksiä ja ristiriitaisuutta. Kirjallisuuden valossa on selkeää, että tällaisen tunteita ja eksistentiaalisia kysymyksiä, jopa henkisiä ja hengellisiä kysymyksiä käsittelevän vaiheen jälkeen on siirryttävä toivon näkö- 
aloihin. Toivoa on käsitelty viimeaikaisessa kansainvälisessä ympäristökasvatuksen tutkimuksessa, mutta monitieteellinen tarkastelu tuo tärkeää lisävaloa toivon ja optimismin suhteeseen.

Monet kirjoittajat käyttävät käsitteitä toivo ja optimismi toistensa synonyymeina, mutta tarkempi erottelu on hyödyllistä. Optimismi viittaa enemmän onnistumis-uskoon, kun taas toivo korostaa tietynlaista asennetta ja sen kautta syntyvää merkityksellisyyttä (Eagleton 2015). Tämä on olennainen ero ilmastonmuutoksen aikana, sillä realistisesti arvioituna ei ole mitään takeita siitä, että ihmiskunta onnistuu riittävällä tavalla ilmastonmuutoksen hillitsemisessä ja siihen sopeutumisessa. Mutta vaikka optimismi olisi vaikeaa, toivon asenne on silti mahdollista ja olennaista.

Ympäristökasvatukseen liittyvässä kirjallisuudessa näitä näkökulmia ovat analysoineet filosofisemmin David Orr (2009) ja käytännön tutkimuksissa Maria Ojala $(2007,2012,2016)$. Ojalan nuorten parissa tekemät tutkimukset ovat osoittaneet toivon olennaisen merkityksen. Hän erottelee perusteettoman toiveajattelun (wishful thinking) and rakentavan toivon (constructive hope). Pelkästään jonkinlaisen toiveikkuuden esiintyminen ei aina osoittautunut hyödylliseksi, vaan tarvittiin realistisempaa näkemystä, jossa oma vastuu tunnustettiin riittävällä tavalla.

Useat syvälliset ajattelijat, kuten Orr ja filosofi Jonathan Lear, hahmottelevat samankaltaisella tavalla syvempää toivoa. Orr (2009) ja Hicks (2014) käyttävät Learin käsitettä "radikaali toivo". Enemmän kuin Ojala, he korostavat tällaisen toivon tiettyä avoimuutta: radikaali toivo roikkuu kiinni merkityksellisyydessä, vaikka tulevaisuudesta ei ole tietoa tai varmuutta. Kyse on epätoivon vastakohdasta, joka on kirjaimellisesti toivo eikä optimismi (Foster 2015). Käytännössä tällainen asenne yhdistyy tiettyihin hyveisiin, kuten rohkeuteen ja sitkeyteen (teologiassa ks. klassinen Tillich 1952). Vaikutusvaltainen ympäristöajattelija Joanna Macy käyttää Chris Johnstonen kanssa (2012) termiä "aktiivinen toivo". Sellaista toivoa ei niinkään omisteta staattisesti, vaan sitä eletään todeksi: kyseessä on dynaaminen elämänasenne.

\section{Tunteiden ja eksistentiaalisten kysymysten käsittely}

On selvää, että yllä kuvattujen teemojen käsittely on käytännössä haastavaa. Pidän sitä kuitenkin, yhdessä edellä mainittujen ajattelijoiden kanssa, välttämättömänä suuntana, jota kohti on harkitusti edettävä. David Hicks on käsitellyt aihepiiriä vuosien ajan tulevaisuuskasvatus-materiaaleissaan ja niihin liittyvissä akateemisissa teksteissään (esim. 2002, 2014). Hän korostaa, että ohjaajien ja opettajien on ensin itse käytävä läpi näihin teemoihin liittyviä prosesseja, jotta kasvatus- ja vaikuttamistilanteet voivat onnistua paremmin. Muuten vaarana on tiedostamaton tunteiden ja asenteiden välittäminen, kuten pelkojen tai kyynisyyden viestintä. Hicks tuo esiin myös ryhmädynamiikan merkityksen sekä tarpeen arvioida, mihin opettajan ja ryhmän vuorovaikutus sekä opetusjakson pituus antavat mahdollisuuksia. Hicks ja Bord (2001, s. 424) kuvaavat nuorten opiskelijoiden lähtötilannetta ja kasvattajien tehtäviä syvällisesti:

Many first year students arrive with what might be described as false hope or unrealistic optimism about the world, partly through lack of knowledge but also because they themselves have yet to be tempered by life. In a sense the task is an existential one - to shatter their 
Ainedidaktiikka 1(1) (2017)

innocence about the human condition so that a more grounded journey can begin. The real betrayal would be not to awaken them to the human/global condition. As Macy and Brown ... argue, the heart has to be broken in order for there to be an awakening of wider compassion. A true sense of empowerment thus comes from both head and heart - but this requires educators who have also worked through these issues for themselves. Only then can we really begin to help students gather resources for a journey of hope.

Sekä Hicks (2014) että Orr (2009) kertovat myös vastustuksesta, jota näiden aihepiirien käsittely etenkin ensi alkuun herättää monissa opettajissa. Tämä liittyy ylipäätään tunteiden käsittelyn puutteisiin nykyisessä kasvatuksessa ja aihepiirin vaikeaksi kokemiseen opettajien ja kasvattajien keskuudessa (vrt. Selby 2011). Käytännön etenemiskeinoja tässä asiassa on tarpeen miettiä moniammatillisesti. Henkilökohtaisen ja pienryhmissä tapahtuvan prosessoinnin materiaaliksi on tarjolla Macyn ja Johnstonen (2012) sekä Mary Pipherin (2013) teokset, ja suomeksi esimerkiksi Kirsi Salosen (2010) eko- ja ympäristöpsykologiaa käsittelevä kirja.

\section{Kokonaisvaltaisuuden olennaisuus: keinoina taideperustaiset meto- dit}

Ympäristökasvatuksen teoriakirjallisuudessa on jo pitkään korostettu tarvetta integroida tieto, tunne ja toiminta (esim. Palmer 1998). Yllä esitetyt näkökulmat lisäävät entisestään kokonaisvaltaisuuden tarvetta. Tunteiden ja eksistentiaalisten kysymysten käsittelyssä tarvitaan monipuolisia metodeja.

Taideperustainen ympäristökasvatus vaikuttaa erityisen tärkeältä tällaisen kokonaisvaltaisuuden saavuttamiseksi. Luova ja taiteellinen toiminta voi auttaa murtamaan niitä vaikenemisen muotoja, joita arjessa esiintyy. Erilaiset tunteet ja ympäristöahdistus voivat päästä käsiteltäviksi. Suomessa kehitetään kiitettävästi taideperustaista ympäristökasvatusta ja alalta on ilmestynyt uutta hyvää kirjallisuutta (van Boeckel 2013; Suominen [toim.] 2016).

Taideperustaisen ympäristökasvatuksen kirjallisuudessa on hivenen käsitelty ympäristöahdistusta (van Boeckel 2009), mutta vielä on tarvetta integroida lisää niitä näkökulmia, joita yllä on esitetty. Draamalliset metodit tarjoavat hyvin lupaavia mahdollisuuksia tragedian ja toivon käsittelyyn. Esimerkiksi draama, jota osallistujat toteuttavat itse, voi tarjota syviä mahdollisuuksia sekä ahdistuksen käsittelyyn että vapauttavan katharsiksen kokemiseen (Lehtonen 2015; Lehtonen, Salonen \& Cantell [tulossa]).

Kaikkien aineiden opetuksessa ei ole yhtä yksinkertaista käyttää taideperustaisia metodeja, mutta on syytä huomioida, että esimerkiksi elokuvien käyttö liittyy tähän lähestymistapaan. Myös puhtaammin luonnontieteisiin liittyvissä opetus- ja kasvatustilanteissa voidaan esimerkiksi katsoa ilmastonmuutokseen liittyviä elokuvia, joissa usein on mukana luonnontieteilijöitä haastateltavina. Elokuvat auttavat tunneulottuvuuksien mukaan tuomisessa ja tarjoavat ryhmäkeskusteluille hyviä kiintopisteitä. Tuoreita tällaisiin tarkoituksiin hyvin soveltuvia elokuvia ovat kokemukseni mukaan Before the flood (2016), Tulevilla rannoilla (2017) ja How to let go of the world and love all the things climate can't change (2016). Eri- 
laisten taideteosten tarkastelussa ympäristönäkökulmiin liittyen voi hyödyntää niin sanotun ekokritiikin tutkimuskirjallisuutta (ks. Buell 2005; monitieteellisistä näkökulmista suomeksi ks. Lummaa, Rönkä \& Vuorisalo 2012).

\section{Henkisyys / hengellisyys, katsomusaineet ja ympäristökasvatus}

Taideperustaiset metodit tuottavat parhaimmillaan syviä kokemuksia, jotka koskettavat sekä ruumista että mieltä, sekä ajatuksia että tunteita. Nämä seikat luovat yhteyksiä taideperustaisten metodien ja henkisen/hengellisen kokemisen välille. Henkisyys voidaan määritellä eri tavoin, esimerkiksi vastakohtana perinteisemmälle uskonnollisuudelle (spirituality / religion). Tässä artikkelissa liityn kuitenkin niihin henkisyyden määrittelyihin, joissa "spirituality" nähdään yhdistyvän merkittäviin kokemuksiin, joissa käsitellään ja kohdataan jotain syvää ja/tai itseä suurempaa (ks. Trigwell, Francis \& Bagot 2014, ss. 242-243; Vilja-Mantere 2016). Tällä tavoin määriteltynä monet sellaiset kokemukset, joista suomeksi osa ihmisistä käyttäisi määrettä hengellinen, liittyvät yhtä lailla asiaan.

Henkisyyden, hengellisyyden ja ympäristökasvatuksen leikkauspinta vaatii selvästi lisätutkimusta, vaikka esimerkiksi luontoympäristöjen henkistä / hengellistä kokemista onkin tutkittu (ks. esim. Hedlund-De Witt 2013). Tämän artikkelin aiheen kannalta olennaista on, että ympäristöahdistukseen liittyvien syvien tunteiden ja eksistentiaalisten kysymysten käsittelyssä voidaan hyödyntää henkisiä ja hengellisiä kokemuksia. Esimerkiksi katsomusaineiden opetuksessa voidaan perehtyä siihen, millä tavoin eri katsomukset ja uskonnolliset yhteisöt käsittelevät ympäristöahdistusta tai siihen verrattavissa olevia asioita. Uskonnolliset yhteisöt ovat esimerkiksi kehittäneet hartaudellista toimintaa, jonka puitteissa käsitellään ympäristöasioita (Ingram 1996). Uskonnollisten yhteisöjen ympäristötoimintaa ja -ajattelua tutkitaan kansainvälisesti kasvavassa määrin (ks. Taylor [toim.] 2005). Myös niiden ympäristökasvatustoimintaa on tarkasteltu (Hitzhusen 2006; Pihkala 2011; Toh \& Cavagas 2010).

Esimerkiksi sekulaari ilmastoajattelija George Marshall (2014) onkin suositellut, että ilmastokasvatuksessa kannattaisi hyödyntää uskonnollisten yhteisöjen parhaita käytäntöjä syyllisyyden käsittelyssä ja yhteisöllisen toivon sekä toiminnan rakentamisessa. Opetusta suunniteltaessa ja tutkittaessa on vuorostaan tärkeää tarkastella sitä, miten katsomusaineissa itsessään käsitellään ympäristöteemoja (vrt. Aarnio-Linnanvuori 2013).

Yksi tärkeä lisätutkimuksen aihe olisi rituaalisuuden ja ympäristökasvatuksen yhteyksien tarkastelu, jossa on liittymäkohtia sekä draamallisiin metodeihin että henkisyyteen / hengellisyyteen. Rituaalitutkimus on kansainvälisesti kasvava ala, jossa tarkastellaan sekä virallisempia rituaaleja että arkielämän puolihuomaamatonta rituaalisuutta (ks. Grimes 2014). Kasvatuksessa ja kouluissa on ikiaikaisesti toteutettu rituaalisuutta - esimerkiksi päivänavauksia ja koulun juhlia voi tarkastella tätä kautta -, mutta tietääkseni aihetta ei ole tarkasteltu kattavasti etenkään ympäristökasvatuksen osalta (kristinuskosta ja ympäristökasvatuksesta Suomen kouluhistoriassa ks. Pihkala 2011). Monissa toimiviksi havaituissa ympäristökasvatuksen muodoissa kuitenkin ilmenee selkeää rituaalinomaisuutta, kuten tietyn rakenteen saaneissa retkissä ja luontoon liittyvien merkkipäivien vietossa (Amerikan osalta vrt. Schmidt 1991). 


\section{Yhteenveto johtopäätöksistä}

Tässä artikkelissa tarkastelin monien eri alojen tutkimusten perusteella sitä, millä tavoin ympäristökasvatuksessa tulisi käsitellä maailman ongelmia. Olennaisessa roolissa on tutkimus niin sanotusta ympäristöahdistuksesta ja erilaisista psykologisista sekä sosiaalisista kieltotiloista. Tuoreet tutkimukset paljastavat, että ihmiset tietävät laajasti ympäristöongelmista, mutta heidän on vaikea käsitellä asiaan liittyviä tunteita ja ajatuksia.

Aineiston analyysin pohjalta esitin oman näkemykseni siitä, millä tavoin ympäristökasvatuksessa olisi tuotava esiin sekä traagisuutta että toivoa. Maailman ongelmia on käsiteltävä riittävällä vakavuudella, jotta ihmiset pitävät ympäristökasvatusta uskottavana ja kokemusmaailmaansa vastaavana. Samalla on huolehdittava siitä, että draaman kaari vie kohti voimaantumista, jossa toivo on keskeinen merkityksen ja voimien antaja. Tällainen metodiikka vaatii erityishuomion kiinnittämistä kasvatus- tai vaikuttamistilanteen vuorovaikutukselliseen dynamiikkaan. Sen suhteen olennaiseksi piirtyvät sellaiset asiat kuten yhtäältä tilanteen ohjaajan (tai opettajan) ryhmädynaamiset taidot ja ymmärrys psykologisista torjuntamekanismeista, ja toisaalta osallistujien motivaatio sekä lähtökohtainen toimintavalmius.

Liityin eräiden ympäristökasvatuksen tutkijoiden ja toteuttajien, kuten David Hicksin ja Elin Kelseyn korostuksiin siitä, kuinka tunteisiin ja eksistentiaalisiin kysymyksiin on kiinnitettävä lisää huomiota. Tällaisessa toiminnassa taideperustaiset metodit, kuten draama, tarjoavat olennaisen tärkeitä mahdollisuuksia. Taustalla on laajemminkin henkisten ja hengellisten asioiden rooli ympäristökasvatuksessa, mitä tarkastelin sekä henkisten kokemusten että katsomusaineiden opetuksen suhteen. Esitin, että rituaalitutkimuksen soveltaminen ympäristökasvatukseen olisi tärkeä lisätutkimuksen aihe.

Artikkelini loi uudenlaisia monitieteellisiä yhteyksiä etenkin ympäristöpsykologian ja ympäristökasvatuksen välille, mutta tarkasteluni kosketti myös sellaisia aloja kuin ympäristöpolitiikka, ympäristösosiologia, ympäristöteologia, ympäristöviestintä, ympäristöetiikka ja ympäristöfilosofia. Pääpaino oli humanistis-yhteiskunnallisessa ympäristötutkimuksessa, mutta eräät alat, joista keskustelin, kuten evoluutiopsykologia, sijoittuvat luonnontieteiden rajamaille. Käytännön menetelmien kehittäminen yllä esitettyjen linjojen mukaisesti vaatii monialaista keskustelua, johon olen pyrkinyt tällä artikkelilla antamaan virikkeitä.

\section{Lähteet}

Aarnio-Linnanvuori, E. (2013). Environmental Issues in Finnish School Textbooks on Religious Education and Ethics. Nordidactica (1), 131-157.

Berryman, T. \& Sauvé, L. (2013). Languages and Discources of Education, Environment, and Sustainable Development. Teoksessa R. B. Stevenson, M. Brody, J. Dillon \& A. E. J. Wals (toim.), International Handbook of Research on Environmental Education (ss. 133-146). New York \& London: Routledge.

Boeckel, J. van. (2013). At the Heart of Art and Earth: An Exploration of Practices in Arts-Based Environmental Education (Väitöskirja). Helsinki: Aalto University.

Boeckel, J. van. (2009). Arts-Based Environmental Education and the Ecological Crisis: Between Opening the Senses and Coping with Psychic Numbing. Teoksessa B. Drillsma-Milgrom \& L. Kirstinä (toim.), Metamorphoses in Children's Literature and Culture (ss. 145-164). Turku: Enostone. 


\section{Ainedidaktiikka 1(1) (2017)}

Buell, L. (1995). The Environmental Imagination: Thoreau, Nature Writing, and the Formation of American Culture. Cambridge: Belknap.

Buell, L. (2005). The Future of Environmental Criticism: Environmental Crisis and Literary Imagination. Blackwell Manifestos. Malden: Blackwell.

Chang, C. H. (2014). Climate Change Education: Knowing, Doing and Being. Oxfordshire: Routledge.

Clayton, S., Manning, C. \& Hodge, C. (2014). Beyond Storms \& Droughts: The Psychological Impacts of Climate Change. Washington: APA and ecoAmerica.

Cohen, S. (2001). States of Denial: Knowing about Atrocities and Suffering. Cambridge: Polity.

Dickinson, J. L., Crain, R., Yalowitz, S., \& Cherry, T. M. (2013). How Framing Climate Change Influences Citizen Scientists' Intentions to do Something about it. Journal of Environmental Education 44(3), 145-158.

Doherty, T. J. \& Clayton, S. (2011). The Psychological Impacts of Global Climate Change. American Psychologist 66(4), 265-76.

Eagleton, T. (2015). Hope without Optimism. Charlottesville and London: University of Virginia Press.

Eckersley, R. (2008). Nihilism, Fundamentalism, or Activism: Three Responses to Fears of the Apocalypse. Futurist 42(1), 35-39.

Foster, J. (2015). After Sustainability: Denial, Hope, Retrieval. London and New York: Routledge.

Fritze, J., Blashki, G.A., Burke, S. \& Wiseman, J. (2008). Hope, Despair and Transformation: Climate Change and the Promotion of Mental Health and Wellbeing. International Journal of Mental Health Systems 2(1), 13.

Gibbons, A. (2013a). The Teaching of Tragedy: Narrative and Education. Educational Philosophy \& Theory 45(11), 1150-1161.

Gibbons, A. (2013b). Tragedy and Teaching: The Education of Narrative. Educational Philosophy \& Theory 45(11), 1162-1174.

Grimes, R. L. (2014). The Craft of Ritual Studies. New York: Oxford University Press.

Gough, A. (2013). The Emergence of Environmental Education Research. Teoksessa R. B. Stevenson, M. Brody, J. Dillon \& A. E. J. Wals (toim.), International Handbook of Research on Environmental Education (ss. 13-22). New York: Routledge.

Hedlund-De Witt, A. (2013). Pathways to environmental responsibility: A qualitative exploration of the spiritual dimension of nature experience. Journal for the Study of Religion, Nature and Culture 7(2), 154-186.

Hicks, D. (2014). Educating for Hope in Troubled Times: Climate Change and the Transition to a Post-Carbon Future. London: Institute of Education Press.

Hicks, D. (2002). Lessons for the Future: The Missing Dimension in Education. Futures and Education Series. London: Routledge.

Hicks, D. \& Bord, A. (2001). Learning about Global Issues: Why Most Educators Only Make Things Worse. Environmental Education Research 7(4), 413-425.

Hitzhusen, G.A. (2006). Religion and Environmental Education: Building on Common Ground. Canadian journal of environmental education 11(1), 9-25.

Ingram, Beryl. (1996). Eco-Justice Liturgies. Teoksessa D. Hessel (toim.), Theology for Earth Community: A Field Guide (ss. 250-264). New York: Orbis.

Jacquet, J. (2015). Is Shame Necessary? New Uses for an Old Tool. New York: Pantheon Books.

Jolkkonen, J. (2007). Systemaattinen analyysi tutkimusmetodina. Metodiopas. Joensuu: Joensuun yliopiston teologinen tiedekunta. Saatavilla https://www2.uef.fi/documents/11461/898474/systemaattinen_analyysi tutkimusmetodina.pdf (luettu 15.2.2017).

Kelsey, E. \& Armstrong, C. (2012). Finding Hope in a World of Environmental Catastrophe. Teoksessa A. E. J. Wals \& P. B. Corcoran (toim.), Learning for Sustainability in Times of Accelerating Change (ss. 187-200). Netherlands: Wageningen Academic Pub.

Kollmuss, A. \& Agyeman, J. (2002). Mind the Gap: Why do People Act Environmentally and what are the Barriers to Pro-Environmental Behavior? Environmental Education Research 8(3), 239-260.

Lehtonen, A. (2015). Calls for Creative Collaboration: How Can Drama Provide Creative and Collaborative Learning Methods for Climate Change Education? Nordisk Dramapedagogisk Tidskrift 52(3), 34-37. 


\section{Ainedidaktiikka 1(1) (2017)}

Lehtonen, A., Cantell, H. \& Salonen, A. (tulossa). Climate Change Education in the Era of Anthropocene. Teoksessa J. Lähdemäki \& J. Cook (toim.), Learning at the Edge of History. London: Palgrave Macmillan.

Lertzman, R. A. (2015). Environmental Melancholia: Psychoanalytic Dimensions of Engagement. Hove and New York: Routledge.

Lummaa, K., Rönkä, M., \& Vuorisalo, T. (2012). Monitieteinen ympäristötutkimus. Helsinki: Gaudeamus.

Macy, J. \& Johnstone, C. (2012). Active Hope: How to Face the Mess We're in without Going Crazy. Novato: New World Library.

Marshall, G. (2015). Don't Even Think about it: Why our Brains are Wired to Ignore Climate Change. New York: Bloomsbury Publishing USA.

Miceli, M. \& Castelfranchi, C. (2010). Hope: The Power of Wish and Possibility. Theory \& Psychology 20(2), 251-276.

Mykrä, N. (2016). Opetussuunnitelma ja ympäristökasvatus (päivitetty 21.7.2016). http://www.luontokoulut.fi/ops2016/ (luettu 15.1.2017.)

Myllyniemi, S. (toim.) (2017). Katse tulevaisuudessa: Nuorisobarometri 2016. [Helsinki]: Opetus- ja kulttuuriministeriö, Valtion nuorisoneuvosto ja Nuorisotutkimusseura.

Nicholsen, S. W. (2002). The Love of Nature and the End of the World: The Unspoken Dimensions of Environmental Concern. Cambridge: MIT Press.

Norgaard, K. M. (2011). Living in Denial: Climate Change, Emotions, and Everyday Life. Cambridge: MIT Press.

Ojala, M. (2012). Hope and Climate Change: The Importance of Hope for Environmental Engagement among Young People. Environmental Education Research 18(5), $625-642$.

Ojala, M. (2007). Hope and Worry: Exploring Young People's Values, Emotions, and Behavior regarding Global Environmental Problems. Örebro University: Universitetsbiblioteket.

Ojala, M. (2016). Young People and Global Climate Change: Emotions, Coping, and Engagement in Everyday Life. Teoksessa N. Ansell, N. Klocker \& T. Skelton (toim.), Geographies of Global Issues: Change and Threat (ss. 1-19). Singapore: Springer.

Orr, D. W. (2009). Down to the Wire: Confronting Climate Collapse. Oxford: Oxford University Press.

Palmer, J. A. (1998). Theory of Environmental Education. Florence: Routledge.

Pihkala, P. (2017). Environmental Education After Sustainability: Hope in the Midst of Tragedy. Global Discourse 7(1).

Pihkala, P. (2016). Apatiasta kestävään elämään". Helsinki: Sitra. https://www.sitra.fi/blogit/apatiasta-kestavaan-elamaan/ (Luettu 1.12.2016.)

Pihkala, P. (2011). Maailmankatsomukset ja kristinusko ympäristökasvatuksessa. Kasvatus \& Aika 5(4). http://www.kasvatus-ja-aika.fi/site/?lan=1\&page id=439 (Luettu 11.11.2016.)

Pipher, M. (2013). The Green Boat: Reviving Ourselves in our Capsized Culture. New York: Riverhead Books.

Radkau, J. (2014). The Age of Ecology: A Global History. Cambridge: Polity Press.

Randall, R. (2013). Great Expectations: The Psychodynamics of Ecological Debt. Teoksessa S. Weintrobe (toim.), Engaging with Climate Change: Psychoanalytic and Interdisciplinary Perspectives (ss. 87-102). London and New York: Routledge.

Salonen, A. \& Konkka, J. (2017). Kun tyytyväisyys ratkaisee: nuorten suhtautuminen globaaleihin haasteisiin, käsitykset ihanneyhteiskunnasta ja toiveet omasta tulevaisuudesta. Teoksessa Katse tulevaisuudessa: Nuorisobarometri 2016 (ss. 137156). [Helsinki]: Opetus- ja kulttuuriministeriö.

Salonen, K. (2010). Mielen luonto: Eko- ja ympäristöpsykologinen näkökulma. Helsinki: Green Spot.

Sapiains, R., Beeton, R. J. S. \& Walker, I. A. (2015). The Dissociative Experience: Mediating the Tension between People's Awareness of Environmental Problems and their Inadequate Behavioral Responses. Ecopsychology 7(1), 38-47.

Schmidt, L. E. (1991). From Arbor Day to the Environmental Sabbath: Nature, Liturgy, and American Protestantism. Harvard Theological Review 84(3), 299-323. 


\section{Ainedidaktiikka 1(1) (2017)}

Selby, D. E. (2011). Education for Sustainable Contraction as Appropriate Response to Global Heating. Journal for Activist Science and Technology Education 3(1), 114.

Skrimshire, S. (toim.) (2010). Future Ethics: Climate Change and Apocalyptic Imagination. London: Bloomsbury Publishing.

Smith, P. \& Howe, N. (2015). Climate Change as Social Drama: Global Warming in the Public Sphere. Cambridge: Cambridge University Press.

Stevenson, R. B., Dillon, J., Wals, A. E. J. \& Brody, M. (2013). The Evolving Characteristics of Environmental Education Research. Teoksessa R. B. Stevenson, M. Brody, J. Dillon \& A. E. J. Wals (toim.), International Handbook of Research on Environmental Education (ss. 512-517). New York: Routledge.

Stoknes, P. E. (2015). What We Think About When We Try Not to Think about Global Warming: Toward a New Psychology of Climate Action. White River Junction: Chelsea Green Publishing.

Suominen, A. (toim.) (2016). Taidekasvatus ympäristöhuolen aikakaudella: Avauksia, suuntia, mahdollisuuksia. Aalto-Yliopiston Julkaisusarja - Taide + Muotoilu + Arkkitehtuuri 3/2016. Helsinki: Aalto ARTS books.

Taylor, B. R. (toim.) (2005). The Encyclopedia of Religion and Nature. New York: Continuum.

Tillich, P. (1952). The Courage to Be. New Haven: Yale University Press.

Toh, S-H. \& Cawagas, V. F. (2010). Transforming the Ecological Crisis: Challenges for Faith and Interfaith Education in Interesting Times. Teoksessa F. Kagawa \& D. Selby (toim.), Education and Climate Change: Living and Learning in Interesting Times (ss. 175-196). London and New York: Routledge.

Trigwell, J. L., Francis, A. J. P. \& Bagot, K. L. (2014). Nature Connectedness and Eudaimonic Well-Being: Spirituality as Potential Mediator. Ecopsychology 6(4), 241251.

Vilja-Mantere, J. (2016). Minua suurempaa? Maisemakokemus, raja ja pyhä. Teoksessa A. Suominen (toim.), Taidekasvatus ympäristöhuolen aikakaudella (ss. 143-153). Helsinki: Aalto ARTS books.

Wallace, J. (2007). The Cambridge Introduction to Tragedy. Cambridge: Cambridge University Press.

Weintrobe, S. (2013). The Difficult Problem of Anxiety in Thinking about Climate Change. Teoksessa S. Weintrobe (toim.), Engaging with Climate Change: Psychoanalytic Perspectives (ss. 33-47). London and New York: Routledge.

Zerubavel, E. (2006). The Elephant in the Room: Silence and Denial in Everyday Life. Oxford: Oxford University Press.

Zeyer, A. \& Kelsey, E. (2013). Environmental Education in a Cultural Context. Teoksessa R. B. Stevenson, M. Brody, J. Dillon \& A. E. J. Wals (toim.), International Handbook of Research on Environmental Education (ss. 206-212). New York \& London: Routledge. 


\title{
Ainedidaktiikka 1(1) (2017)
}

\begin{abstract}
The article analyzes the challenges of environmental education (EE) in the current situation. New research has revealed the existence of strong psychological and social defense mechanisms, which causes the need to re-think the ways in which environmental threats and problems are treated. EE is here defined in a broad manner, including such fields as Education for sustainability and Climate education. The method is systematic analysis of results from many disciplines and of the concepts used therein. Based on the analysis, the article proposes new recommendations for EE. Environmental threats and problems must be treated in a manner which is realistic enough, for otherwise contemporary people, including students, do not regard EE as credible. At the same time, the wider narrative structure of EE events must lead towards empowerment. Hope is seen as a central concept. The article discusses such themes as the role of narratives, emotions, existential and spiritual factors, and the use of art-based methods.
\end{abstract}

environmental education, philosophy, communication, psychology, study of religions 